\title{
Values and Lifestyle of Czech Families - A Sociological Research
}

\section{An introduction to the problem}

After the fall of communism in the Czech Republic, several sociological studies have been conducted analysing the values and lifestyle of the Czech population. Each study has its own characteristics and offers interesting sociological indicators. To a satisfactory extent the studies present basic values, important for today's society, which have a fundamental influence on families and social life. On the basis of these studies, we can better understand the problems of transmitting faith in families ${ }^{1}$.

The results of sociological research on religiosity have been published by the Czech Statistical Office (CZSO). The data have been acquired from the population census in 1991, 2001 and 2011. A comparative and detailed analysis of the first

* MARIUSZ KUŹNIAR - ( ${ }^{*} 1970$, Nysa, Poland, ordained 1995) graduated from Charles University in Prague. Licentiate in Catechetics at Opole University (Poland), Th.D. in Catechetics (2011) at Università Pontificia Salesiana (Rome, Italy). Since 2011 director of Department for Catechesis at Czech Bishops' Conference. Assistant of Catholic Theological Faculty at Charles University in Prague.

1 This part of the monograph was written within a research project conducted at Charles University in Prague called: PRVOUK 01 “Theology as a way of interpreting history and culture”. 
two censuses has been provided by Ladislav Pištora ${ }^{2}$. The results of the last census concerning faith and religion have not been made public yet ${ }^{3}$.

In the new economic and political reality of the Czech Republic, the European Values Study (EVS) took place, a comprehensive and longitudinal comparative research providing scientific information on beliefs, preferences, attitudes, values and opinions of citizens in different European countries. The first wave of the survey was conducted in 1981 in only 10 western European countries. The second wave took place in 1990, covering 26 countries. The Czech Republic, as a new democratic state, joined the project in 1991. The third EVS wave was realized in 1999 with the participation of 32 countries. The fourth wave of the survey was conducted in 2008 in 47 European countries ${ }^{4}$. The EVS provides insight into the development of European communities over the course of more than 40 years and allows review of the dynamics of change. It especially focuses on basic issues of social life, such as work, family, marriage, education, leisure time, politics, social commitment, faith, religiosity, ethics, tolerance, etc. Ladislav Rabušic and Jan Spousta have published several articles based on this research ${ }^{5}$.

The International Social Survey Programme (ISSP) provides another interesting set of data ${ }^{6}$ from a study in which the Institute of Sociology of the Academy of Sciences of the Czech Republic participated. In June 1999, a sociological study was conducted

2 See L. Pištora, Občan a jeho vztah k náboženství či viře v údajích sčítání lidu, Teologie \& Společnost I. (IX.) 2003, 6, p. 33-36.

3 Statistical Yearbook of the Czech Republic 2012, Praha 2012, Czech Statistical Office.

4 In 1991, the EVS research in the Czech Republic was conducted by the Institute of Sociological Studies FSS CU in Prague (J. Řehák, I. Bártová, J. Kabele); In 1999, the third EVS wave was organized by L. Rabušic together with J. Řehák and the SC\&C agency; In 2008, the fourth wave of the survey took place, conducted by the team led by L. Rabušic and J. Hamanová from the SC\&C agency.

5 L. Rabušic, České hodnoty 1991-1999, Brno 2001, Masarykova universita; J. Spousta, České církve očima sociologických výzkumů, in: Náboženství v době společenských změn, J. Hanuš (ed.), Brno 1999, Masarykova univerzita, p. 73-90; J. Spousta, Changes in Religious Values in the Czech Republic, "Sociologický časopis / Czech Sociological Review" 38 (2002), p. 345-364.

6 The International Social Survey Programme is a project of international sociological studies on topics important for social sciences. The ISSP researchers develop questions which are meaningful and relevant to all countries and can be expressed in an equivalent manner in different languages. The studies provide a cross-national and cross-cultural perspective to the individual national studies. Since 2009, the programme has included 46 member countries. In 1999, an analysis of religiosity of the Czech population was provided in cooperation with the SC\&C agency. 
in cooperation with the SC\&C agency concerning religious belief, social behaviour, political and moral attitudes, individual ethics and attitudes to sexual and domestic violence. Analysis of the results was presented by Dana Hamplová ${ }^{7}$.

Studies have been also published by Petr $\mathrm{Sak}^{8}$ in cooperation with the Insoma Agency, providing interesting information on preferences, structure and orientation of young people today.

These and other sources, provide insight into the problem of religiosity in families. The fact that there are 36 registered churches and religious societies in the Czech Republic today ( 9 of them already registered in Austria-Hungary, the rest in the independent Czech Republic) shows the dynamics and diversity of contemporary Czech society. It is an interesting phenomenon but is not easy to explain?

\section{Religious beliefs of the population of the Czech Republic - CZSO ${ }^{10}$}

The first national census after World War II was carried out in 1950. It was the last census in which church membership was surveyed. During the Communist period, population censuses took place regularly, yet questions about spiritual life were removed from questionnaires. After the fall of the "Iron Curtain", religious belief was again included in official questionnaires sent to all citizens in the 1991 census.

Once each decade, the Czech Statistical Office analyses, among other things, religious belief of people in the population and housing census. The data are very valuable from a scientific perspective. The results of the 1991 census show relatively large religious inclination as part of the general euphoria over the fall of communism. The last census took place in 2011. Although religious belief might not be expected to show major changes, data from 2001 and 2011 are markedly different compared to 1991.

7 See D. Hamplová, Náboženství a nadpřirozeno ve společnosti, Praha 2000, Sociologický ústav AV ČR.

8 See P. Sak, Proměny české mládeže, Praha 2000, Nakladatelství Petrklíč; P. Sak, K. Saková, Mládež na křižovatce, Praha 2004, Svoboda Servis.

9 Ministry of Culture. http://www.mkcr.cz/cz/cirkve-a-nabozenske-spolecnosti/registracea-evidence/data-registrace-cirkvi-a-nabozenskych-spolecnosti-a-svazu-cirkvi-a-nabozenskychspolecnosti-11263/ (28.11.2013).

10 Czech Statistical Office. 
Due to gradual secularization of Czech society, not solely as a result of the Communist regime, the number of believers in the Czech Republic has been continually decreasing since 1991. In that year, $43.9 \%$ of citizens identified themselves as believers. In 2001, the number had decreased to approximately one third of the entire population (32.2\%) affiliated with a religion. By the last census in 2011 , only $14 \%$ of people were affiliated with a religious faith. The percentage of the population describing themselves as having no religious affiliation shows a different pattern, increasing from $39.9 \%$ in 1991 to 59\% in 2001, representing more than 6 million people. By 2011, however, this number had decreased to $35 \%$. Due to the fact that declaring religious belief in questionnaires had only a declaratory and not obligatory character, the rest of the population was included in the category "not filled in". In 1991, this amounted to $16.2 \%$ of the population, decreasing to $8.8 \%$ in 2001 . In 2011 this number increased significantly to $45 \%$ of the entire population ${ }^{11}$.

The graph below shows summary results of all censuses carried out in the new liberal and democratic reality of Czech society.

Graph: Population by religious belief

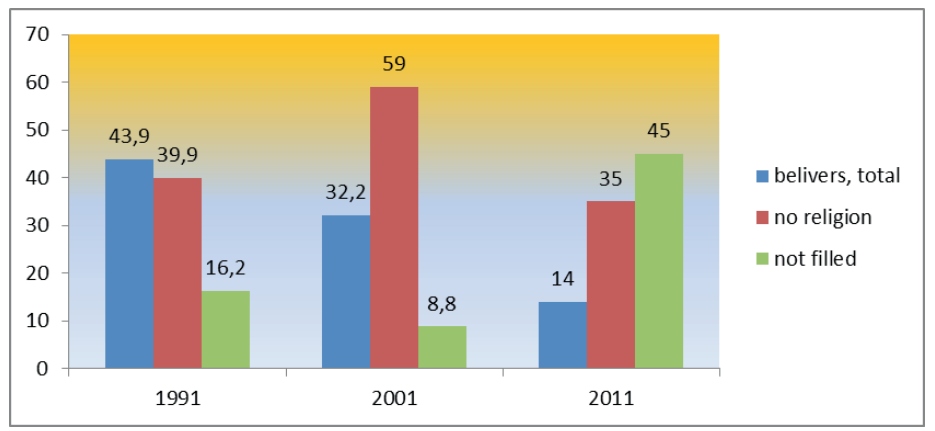

Source: Czech Statistical Office

The problem of deepening secularization of Czech society, manifested in the loss of believers, among other things, is permeating all churches, especially the major ones. As a logical result there is an increase of people with no religious affiliation. The population census provides only a partial view of socio-religious reality, since

11 See L. Pištora, Občan a jeho vztah k náboženství či víre v údajích sčítání lidu, Teologie \&Společnost I. (IX.) 2003, 6, p. 33-36; Český statistický úrad, Statistical Yearbook of the Czech Republic 2012, Praha 2012, Czech Statistical Office, p. 792. 
questions about religious affiliation have only a declaratory character and are not mandatory. Declaring a church affiliation has a statistical value, yet the data do not provide other important information concerning, for example, the quality of faith and depth of people's relationship to God.

The data provided by the CZSO shows differences in religiosity between men and women. Women show higher levels of religious affiliation than men and religiosity increases proportionally to age ${ }^{12}$. There is also a correlation between religiosity and education. Among believers, a relatively small number have higher education, and this is related to education, with the educational level of people over 50 being lower ${ }^{13}$. Secularizing tendencies are more observable in the younger generation, e.g. the decline in number of children of believing parents. Young people's attitudes toward religiosity are likely associated with the presence or absence of catechesis in public schools and secularization in Czech society ${ }^{14}$.

Another phenomenon of relevance is the rising emergence of new non-traditional quasi-religious movements such as the order of Jedi Knights ${ }^{15}$. According to the population and housing census of 2011, 15070 people were affiliated with Jediism ${ }^{16}$.

The following table shows data from the last three censuses comparing affiliation with main traditional churches in the Czech Republic.

Table 1: Population by religious belief in detail

\begin{tabular}{|l|c|c|c|c|c|c|}
\hline \multirow{2}{*}{} & \multicolumn{2}{|c|}{1991} & \multicolumn{2}{c|}{2001} & \multicolumn{2}{c|}{2011} \\
\cline { 2 - 7 } & Total & $\%$ & Total & $\%$ & Total & $\%$ \\
\hline Population, total & $\mathbf{1 0 3 0 2 2 1 5}$ & $\mathbf{1 0 0 . 0}$ & $\mathbf{1 0 2 3 0 0 6 0}$ & $\mathbf{1 0 0 . 0}$ & $\mathbf{1 0 4 3 6 5 6 0}$ & $\mathbf{1 0 0 . 0}$ \\
\hline $\begin{array}{l}\text { Believers who identify with } \\
\text { a church or religious society }\end{array}$ & $\mathbf{4 5 2 3 7 3 4}$ & $\mathbf{4 3 . 9}$ & $\mathbf{3 2 8 8 0 8 8}$ & $\mathbf{3 2 . 2}$ & $\mathbf{1 4 6 3 5 8 2}$ & $\mathbf{1 4 . 0}$ \\
\hline
\end{tabular}

12 See D. Hamplová, Náboženství a pohlaví: Proč jsou ženy zbožnější než muži?, Sociologický časopis, Sociologický ústav AV ČR, Praha (2011), 47, 2, p. 297-323.

13 See Český statistický úřad, Náboženské vyznání obyvatelstva, Praha 2003, Czech Statistical Office, p. 25.

14 See L. Pištora, Občan a jeho vztah $k$ náboženství či víre v údajích sčitání lidu, "Teologie \&Společnost” I. (IX.) 2003, 6, p. 33-36.

15 Jediism is a nontheistic new quasi-religious movement based on the philosophical and spiritual ideas of the Jedi as depicted in Star Wars media.

16 See Předběžné výsledky Sčitání lidů, domů a bytů 2011 (15.12.2011). Available online. http://www. czso.cz/sldb2011/redakce.nsf/i/predbezne_vysledky_scitani_lidu_domu_a_bytu_2011 (30.11.2013). 


\begin{tabular}{|l|r|r|r|r|r|r|}
\hline & \multicolumn{2}{|c|}{1991} & \multicolumn{2}{c|}{2001} & \multicolumn{2}{c|}{2011} \\
\cline { 2 - 7 } & \multicolumn{1}{|c|}{ Total } & \multicolumn{1}{c|}{$\%$} & \multicolumn{1}{c|}{ Total } & \multicolumn{1}{c|}{$\%$} & \multicolumn{1}{c|}{ Total } & $\%$ \\
\hline Czechoslovak Hussite Church & 178036 & 1.7 & 99103 & 1.0 & 39229 & 0.4 \\
\hline Roman Catholic Church & $\mathbf{4 0 2 1 3 8 5}$ & $\mathbf{3 9 . 0}$ & $\mathbf{2 7 4 0 7 8 0}$ & $\mathbf{2 6 . 8}$ & $\mathbf{1 0 8 2 ~ 4 6 3}$ & 10.4 \\
\hline $\begin{array}{l}\text { Evangelical Church of Czech } \\
\text { Brethren }\end{array}$ & 203996 & 2.0 & 117212 & 1.2 & 51858 & 0.5 \\
\hline $\begin{array}{l}\text { Other Churches and religious } \\
\text { associations }\end{array}$ & 120317 & 1.2 & 330993 & 3.2 & 290032 & 0.7 \\
\hline $\begin{array}{l}\text { Believers whodo not identify } \\
\text { with a church or religious society }\end{array}$ & $\mathbf{4 1 1 2 8 6 4}$ & $\mathbf{3 9 . 9}$ & $\mathbf{6 0 3 9 9 9 1}$ & $\mathbf{5 9 . 0}$ & $\mathbf{3 6 0 4 0 9 5}$ & $\mathbf{3 5 . 0}$ \\
\hline No religion & $\mathbf{1 6 6 5 6 1 7}$ & $\mathbf{1 6 . 2}$ & $\mathbf{9 0 1 9 8 1}$ & $\mathbf{8 . 8}$ & $\mathbf{4 6 6 2 4 5 5}$ & $\mathbf{4 5 . 0}$ \\
\hline Not filled in & & & & & $\mathbf{7 0 5 3 6 8}$ & $\mathbf{6 . 8}$ \\
\hline
\end{tabular}

Source: Czech Statistical Office

\section{The European Values Study}

The European Values Study (EVS), a large-scale comparative and longitudinal research study, is another important and interesting source of information on beliefs, preferences, attitudes, values and opinions of the people of "Old Europe". It is a European research project providing information on how citizens in individual countries think about life, family, work, religion, etc. The first wave of the research took place in 1981 in western European countries. The Czech Republic joined the project during the second wave in 1991 after the fall of communism. At that time there were 2,109 people participating in the survey. The third EVS wave was realized in 1999 with participation of 1,908 respondents. The fourth wave took place in 2008, sampling 1,821 people. Since the EVS project in the Czech Republic has taken place three times already, it allows review of the dynamics of value and attitude changes in the field of family, partner relationships, economics, work, leisure time, politics, religion and ethics in Czech society ${ }^{17}$.

17 See L. Rabušic, M. Petrová Kafková, České hodnotové proměny 1991-2008 (European Values Study), Brno 2010, Fakulta sociálních studií Masarykovy univerzity; L. Rabušic, J. Hamanová, Hodnoty a postoje v ČR 1991-2008 (Pramenná publikace European Value Study), Brno 2009, Munipress; České hodnotové proměny 1991-2008 (European Values Study), “Sociální Studia” 4 (2010) (vol. 7). 
The data gathered by the EVS analysis show the extent and form of increasing secularism in Czech society. Although churches are traditional institutions of the Christian religion, it is not possible to associate them with the phenomenon of religiosity as such. It seems that the meaning of the religious forms outside the church and their presence in everyday life of many people in Europe has been increasing for three centuries ${ }^{18}$. Nevertheless, Christian churches still have a significant influence on cultural, spiritual, political and social events in many countries, therefore they are an indispensable part of the social structure ${ }^{19}$.

Table 2: Concept of God

\begin{tabular}{|c|c|c|c|c|c|}
\hline Year & $\begin{array}{l}\text { There is } \\
\text { a personal } \\
\text { God }\end{array}$ & $\begin{array}{c}\text { There is some } \\
\text { sort of spirit } \\
\text { or life force }\end{array}$ & $\begin{array}{l}\text { I don't really } \\
\text { think there is } \\
\text { any sort } \\
\text { of spirit, God } \\
\text { or life force }\end{array}$ & $\begin{array}{l}\text { I don't really } \\
\text { know } \\
\text { what to think }\end{array}$ & $\begin{array}{c}\text { Belief in the } \\
\text { existence } \\
\text { of God }\end{array}$ \\
\hline 1991 & $12.2 \%$ & $37.6 \%$ & $23.3 \%$ & $26, .9 \%$ & $36.7 \%$ \\
\hline 1999 & $6.5 \%$ & $50.2 \%$ & $22.3 \%$ & $21.0 \%$ & $39.0 \%$ \\
\hline 2008 & $11.1 \%$ & $28.4 \%$ & $36.6 \%$ & $23.9 \%$ & $34.6 \%$ \\
\hline $\begin{array}{l}\text { Difference } \\
1991-2008\end{array}$ & $-1.1 \%$ & $-9.2 \%$ & $+13.3 \%$ & $-3.0 \%$ & $-2.1 \%$ \\
\hline
\end{tabular}

Source: EVS 1991, EVS 1999, EVS 2008

According to the EVS, in 2008 approximately a third of the Czech population declared their belief in God (see Table 2). Yet the idea of God is not obvious. According to Christian churches, God is considered a person, yet this opinion is not shared by the entire Czech society. The Table 2 shows how complicated the reality is. In 1991, 12.2\% of people declared their "belief in God as a person", decreasing to $6.5 \%$ in 1999. Jan Spousta puts it down to reformulating the question to "belief

18 See D. Lužný, J. Navrátilová, Náboženství a sekularizace v České republice, in: L. Rabušic (ed.), České hodnoty 1991-1999, Brno 2001, Masarykova universita, p. 120.

19 See J. Spousta, České církve očima sociologických výzkumů, in: J. Hanuš (ed.), Náboženství v době společenských změn, Masarykova universita, Brno 1999, p. 73. 
in personal God"20, In 2008, the same formulation was used as in 1999, but the results approximated the 1991 level. In the article titled "Současná česká religiozita v generační perspektivě” (Today’s Czech Religiosity in Generational Perspective), Marie Laudátová and Roman Vido do not agree with Spousta’s opinion. According to them, the decline from $12 \%$ to $6.5 \%$ has become evident in all generations, mostly in the oldest generation (1957-1969), where belief in God as a person reached its lowest rate at 3,5\%. According to them, the phenomenon is difficult to explain. On the basis of the available data, it is possible to suppose there is a significant drift from the traditional Christian concept of God to belief in the existence of indefinite and non-personal force or energy, but the tendency is not supported by 2008 data. A comparison of data from 1991-2008 shows an increasing number of people who believe in "no spiritual or godly force". This corresponds with the increase in the number of people declaring atheism (5.5\% in 1991, to $19 \%$ in 2008$)^{21}$. The increase is evident in all generations. The percentage of nonbelievers is higher among the younger generation. Overall, more people openly declare their atheism ${ }^{22}$.

The topic of religious socialization can also be examined in the EVS data. Early childhood is a period of crucial importance in human life and has a significant influence on identity formation. To a great extent, family upbringing has an influence on religious identification. The transmission of religious faith from parents to children depends on many circumstances such as child's personality, the authenticity of parents' religious beliefs, the difference in parents' religious affiliation etc. ${ }^{23}$ It is evident that parents' influence on transmitting the faith to their children is decreasing today. The younger generation demonstrates a weaker sense of duty to transmitting their faith to their children compared to older generations. The EVS offers several indicators to support this, including questions to determine: 1) the importance of religious faith in upbringing, (as an indication of the extent respondents consider religious belief an important investment which they should transmit to their children), 2) respondents' religious upbringing, 3) Religious service attendance at age 12, and 4) the importance of Baptism after birth.

20 J. Spousta, Changes in Religious Values in the Czech Republic, "Sociologický časopis" (2002), vol. 38 , no. 3 , p. 356 .

21 M. Laudátová, R. Vido, Současná česká religiozita v generační perspektivě, in: České hodnotové proměny 1991-2008. (European Values Study), “Sociální Studia” 4 (2010) (vol. 7), p. 55.

22 M. Laudátová, R. Vido, Současná česká religiozita v generační perspektivě, p. 56-57.

23 M. Laudátová, R. Vido, Současná česká religiozita v generační perspektivě, p. 39. 
In regard to the first indicator, $10 \%$ of respondents declared raising their children to be religious to be important in 1991. In 1999, there is a decrease to $6,5 \%$. In 2008, the number increased to slightly above the 1991 figure, $10,5 \%$. Data available for defining the second indicator include only 1991 data, as the question has not been included in following EVS waves. Three-in-four people of the generation born before 1932 indicate having been raised religious, but only one fifth considered transmitting the faith an important issue. The situation in other generations is similar. In the generations born before 1944, the rate levelled off at $5-6 \%$. It is evident that even in religiously well socialized generations the sense of transmitting the faith is gradually disappearing ${ }^{24}$. In 2008, respondents were also asked about religious service attendance at age 12 and at present. There is a significant difference between the generations born in 1932-1944 and 1945-1956. Among the older generation, around $45 \%$ attended religious services once a month or more at age 12 , whereas in the younger one only $24 \%$ did so.

There appears to be a gradual and significant disengagement in transmitting the faith, based on the importance of Baptism after birth, the last indicator. It is evident that the fact of Baptism itself does not automatically guarantee being educated in the faith. Baptism is, rather, motivated by a sense of commitment to religious socialization. Among people attaching importance to Baptism, there is an evident decline, from $49 \%$ in 1991 to $36 \%$ in 2008. It is evident from the survey that the meaning of Baptism is gradually diminishing along with the passing of older generations ${ }^{25}$.

\section{The ISSP - International Social Survey Programme}

In 1998, the ISSP research was conducted on the topic Religion in the Czech Republic. The survey was provided by Klára Vlachová and the research team on social stratification of the Institute of Sociology of the Academy of Sciences of the Czech Republic within the research project Social Trends. The questionnaire module corresponded with the ISSP research from 1991. The aim of the survey was, among other things, to investigate the influence of religious beliefs, education and activities related to religious education on social, political, moral and other attitudes. Analysis of

24 M. Laudátová, R. Vido, Současná česká religiozita v generační perspektivě, p. 46.

25 M. Laudátová, R. Vido, Současná česká religiozita v generační perspektivě, p. 46-48. 
the results was presented by Dana Hamplová ${ }^{26}$. The study was conducted among the adult population of the Czech Republic, consisting of interviews with 1,224 randomly and anonymously chosen individuals. Data collection was conducted by the SC\&C agency. A standardised interview was chosen as the data collection method.

The ISSP survey showed beyond doubt that the Czech Republic belongs among the most secular countries in Europe. This is especially evident from the following indices ${ }^{27}$ :

- The Catholic Church does not have any significant influence in society;

- There is evidence of lack of trust in traditional institutions, including churches;

- There is a small number of people attending religious services;

- Compared to other European countries, secular values have a greater influence in Czech society.

The survey focused, among other things, on the phenomenon of attending liturgical ceremonies. According to Hamplová, it is possible to divide countries into three groups according to religious affiliation ${ }^{28}$ :

- Catholic countries with a high number of Roman Catholics and low percentage of citizens affiliated with other or no religion (Ireland, Italy, the Philippines);

- Protestant countries with a high number of citizens affiliated with protestant churches and denominations (Northern Ireland, the USA, the former West Germany);

- Secular countries with a significant number of citizens having no religious affiliation (the Czech Republic, the former GDR, the Netherlands, New Zealand, Russia, Great Britain).

The Czech Republic is among secular countries with the smallest influence of a traditional religion on social life. The survey confirmed that there is a relatively low percentage of believers, correlating with a low rate of religious service attendance. A higher rate of believers is evidenced in the rural areas and among the elderly. Belief in the existence of a personal God is not widespread among Czechs. In bigger cities, relatively few people believe in a personal God. Prague, where the number of believers has increased, is an exception.

The elderly and less-educated demonstrate higher levels of belief in God. The number of believers in society and attendance at religious services do not represent the complexity of the religious phenomenon, but they are merely its formal and

\footnotetext{
26 D. Hamplová, Náboženství a nadpřirozeno ve společnosti, Praha 2000, Sociologický ústav AV ČR.

27

D. Hamplová, Náboženství a nadpřirozeno ve společnosti, p. 53.

28

D. Hamplová, Náboženství a nadpřirozeno ve společnosti, p. 14.
} 
insignificant indicator. To a certain extent, they reflect present tendencies in society and its orientation. The table below presents the results.

Table 3: Attendance at religious services according to age - Czech Republic

\begin{tabular}{|c|c|c|c|c|c|c|c|c|}
\hline \multirow[b]{2}{*}{ Age } & & \multicolumn{7}{|c|}{ Attendance at religious services } \\
\hline & & Never & $\begin{array}{l}\text { Less } \\
\text { than } \\
\text { once } \\
\text { a year }\end{array}$ & $\begin{array}{c}\text { Several } \\
\text { times } \\
\text { a year }\end{array}$ & $\begin{array}{l}\text { About } \\
\text { once a } \\
\text { Month }\end{array}$ & $\begin{array}{c}\text { Nearly } \\
\text { every } \\
\text { week }\end{array}$ & $\begin{array}{c}\text { Once } \\
\text { a week } \\
\text { or more }\end{array}$ & Total \\
\hline \multirow{2}{*}{$<24$} & $\%$ & 57.1 & 11.2 & 22.4 & 1.5 & 4.6 & 3.2 & 100.0 \\
\hline & $\mathrm{N}$ & 112 & 22 & 44 & 3 & 9 & 6 & 196 \\
\hline \multirow{2}{*}{$25-34$} & $\%$ & 50.8 & 13.8 & 19.9 & 2.2 & 6.1 & 7.2 & 100.0 \\
\hline & $\mathrm{N}$ & 92 & 25 & 36 & 4 & 11 & 13 & 181 \\
\hline \multirow{2}{*}{$35-44$} & $\%$ & 51.4 & 8.6 & 31 & 1.7 & 3.4 & 3.9 & 100.0 \\
\hline & $\mathrm{N}$ & 119 & 20 & 72 & 4 & 8 & 9 & 232 \\
\hline \multirow{2}{*}{$45-54$} & $\%$ & 46.4 & 11.9 & 28.9 & 3.4 & 5.1 & 4.3 & 100.0 \\
\hline & $\mathrm{N}$ & 109 & 28 & 68 & 8 & 12 & 10 & 235 \\
\hline \multirow{2}{*}{$55-64$} & $\%$ & 46.8 & 12.9 & 23.1 & 1.6 & 3.2 & 12.4 & 100.0 \\
\hline & $\mathrm{N}$ & 87 & 24 & 43 & 3 & 6 & 23 & 186 \\
\hline \multirow{2}{*}{$65-74$} & $\%$ & 35.3 & 7.7 & 28.2 & 5.8 & 9.0 & 14.1 & 100.0 \\
\hline & $\mathrm{N}$ & 55 & 12 & 44 & 9 & 14 & 22 & 156 \\
\hline \multirow{2}{*}{$75+$} & $\%$ & 30.7 & 7.7 & 23.1 & 7.7 & - & 30.8 & 100.0 \\
\hline & $\mathrm{N}$ & 4 & 1 & 3 & 1 & - & 4 & 13 \\
\hline \multirow{2}{*}{ Total } & $\%$ & 48.1 & 11.0 & 25.9 & 2.7 & 5.0 & 7.3 & 100.0 \\
\hline & $\mathbf{N}$ & 578 & 132 & 310 & 32 & 60 & 87 & 1199 \\
\hline
\end{tabular}

Source: ISSP Religion 1998.

According to Dana Hamplová, religious service attendance does not automatically and sufficiently represent the quality of personal faith, but we can surmise that people who frequently attend religious services are also often influenced by the Church in crucial existential questions.

According to the ISSP, the family is a traditional institution, not separable from Christian values. Christianity codifies the family and gives it a specific role and place. The value of family is indispensable. It is considered an ideal in the life 
of society as such. The results of this sociological survey show that the role and meaning of parents in a family do not have a crucial influence on children's faith. Young people's age and surroundings are very important.

A significant component of the surroundings are the spiritual movements present in Czech society, among which the Catholic Church has the greatest influence, since it offers a clear view of family and supports the indispensable role of women ${ }^{29}$. In Czech society, there are two different tendencies: traditional Christianity and other spiritual movements (e.g. spiritualism, gnosticism, hermeticism, neoplatonism, fortune telling and occultism) ${ }^{30}$. The ISSP research shows that $60 \%$ of respondents believe in supernatural signs, $45 \%$ believe in the importance of amulets, $45 \%$ believe in the usefulness of horoscopes.

In conclusion, it is possible to say that according to the survey the traditional Christian values are more deep-rooted in most religious countries. The Czech Republic belongs to the societies where the secularization processes are highly represented. This weakens the influence of the traditional Christian values on the present society $^{31}$.

\section{Value analysis - Petr Sak}

Research focusing on young people begun in 1979 by Petr Sak ${ }^{32}$ allows for monitoring of generational development. In his most important publications he submits data from the period 1993-2002 ${ }^{33}$. The author uses a comparative, analogue, hypothetical and deductive method. The last wave of the research included questions concerning 23 values. Respondents $(\mathrm{N}=1,092)$ were asked to indicate what importance each value has for them personally, with 1 indicating least important, 5 indicating most important. Each value is identified by an index, calculated as a weighted arithmetic mean.

29 See D. Hamplová, Náboženství a nadpřirozeno ve společnosti, Praha 2000, Sociologický ústav AV ČR, p. 38-39.

30 D. Hamplová, Náboženství a nadpřirozeno ve společnosti, p. 38-39.

31 D. Hamplová, Náboženství a nadpřirozeno ve společnosti, p. 38-39.

32 Doc. PhDr. Petr Sak, CSc. is a sociologist and pedagogue occupied with the sociology of youth and education for a long time.

33 See P. Sak, Proměny české mládeže, Praha 2000, Nakladatelství Petrklíč; P. Sak, K. Saková, Mládež na křižovatce, Praha 2004, Svoboda Servis. 
In 1993, values such as God, truth, and knowledge were not included in the questionnaire, but were added in 1997 and 2002. "Health" is indicated as the most important value in all age categories. Ironically, at the same time it is possible to observe an increasing number of young people addicted to drugs and alcohol. Love, an ever-important topic in human life, ranks second place. In 2002, love hit its lowest value compared to the preceding years. The value, peace, is a new and interesting phenomenon. In the 90's this value was not of great importance for young people, but in 2002 it mattered much more, ranked as third, possibly due to the threat of terrorism. Partnership, family and children represent other important values. The family has always been of great importance in Czech society as a traditional institution enabling people to cultivate profound interconnected values such as love or friendship and raise children accordingly. However, in today's society the situation is changing slowly and invisibly. The number of children and marriages is decreasing. Politics is ranked as the last value, God is ranked second last ${ }^{34}$.

In another analysis, the author presents a 'life's most important values' scale according to age groups. The meaning of life's important values, such as family, living for others, peace, politics and health, increases with age. On the contrary, the meaning of values of great general importance gradually decreases. For instance, love and partnership are important for young people at age 19-23, while in other age groups their meaning is gradually decreasing. The meaning of family increases at age $31-45$ and then decreases as in the preceding case $^{35}$.

During the years 1992-2002, the author focused on the spiritual dimension of the person and the phenomenon of religiosity. In these studies, he presents the development of Czechs' attitudes toward these values. A questionnaire was sent to 1007 people, in order to investigate the opinion of young people at age 15-30 on spiritual life, God and the world. The results are summarized in the graphs below showing young people's world view (Figure 2) and their opinion on life after death (Figure 3).

\section{The world view typology presented in Figure $2^{36}$ :}

1. I am an atheist-materialist, the world has a material nature, I don't believe in anything what doesn't have its cause in the material world.

2. I am an atheist, but I believe in the existence of appearances which cannot be explained in a material way.

\footnotetext{
34 See P. Sak, K. Saková, Mládež na křižovatce, Praha 2004, Svoboda Servis, p. 12. 
3. I believe in a personal God, who created the world and intervenes in its affairs.

4. I believe in a personal God, who created the world, but does not intervene in its affairs, the world complies with its own laws.

5. I believe in a spiritual nature of the world. I do not consider the Supreme Principle (God) personal. There is nothing except God, the entire being exists only in God.

6. Other opinion, please specify.

7. I don't know, I have never thought about it.

Figure 2 shows the world view scale of young Czechs. The second question reached the highest rate of all, indicating that more than $41 \%$ of young people declare themselves to be atheists, yet the same people believe in the existence of appearances which cannot be explained in a material way. It is a sort of schizophrenia. More than $20 \%$ of young people clearly declared atheism. They do not believe in anything except matter. Faith in a personal God who cares about the world, was declared by $14 \%$ of young people. On the basis of these studies, it can be stated that in the Czech Republic there are more than $61 \%$ of young people declaring some sort of atheism ${ }^{37}$.

Figure 2. Young people's world view

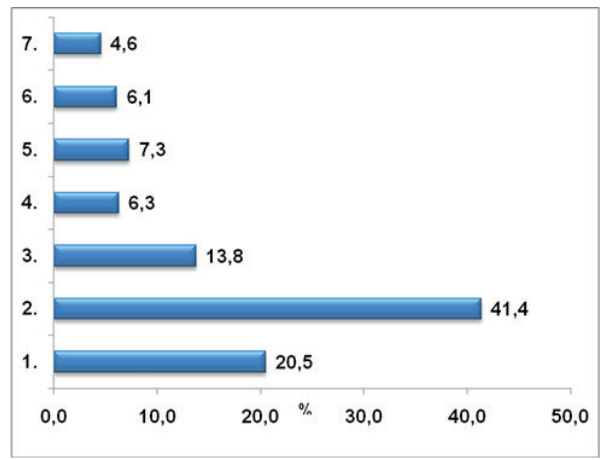

Source: Sak P., in Proměny české mládeže: 1993/1, 1997/1, 2002/2.

The postmortal life typology formulated in answers and presented in Figure $3^{38}$ :

1. Human existence is terminated by death, there is nothing after death.

2. Life after death exists.

37 See P. Sak, Proměny české mládeže, p. 105.

38 See P. Sak, Proměny české mládeže, p. 106. 
3. I believe in the Last Judgement and resurrection.

4. Reincarnation.

5. Spiritual tendencies, interests, deeds (vasanas) cause the rise of another being - existence.

6. Other opinion, please specify.

7. I don't know, I have never thought about it.

Almost $31 \%$ of young Czech adults do not believe in any form of life except the terrestrial one. In other words, they declare there is nothing after death. Besides that, over $22 \%$ believe that life after death exists, but they have no personal view of eternal life. A relatively high number of young people who have never thought about the problem $(16 \%)$ is surprising. Other concepts of postmortal life adopted from great Eastern religions, such as reincarnation, are declared by more than $14 \%$ of young people. Almost $10 \%$ believe in the Last Judgement and resurrection of the body. Only a small number of people (slightly more than $2 \%$ ) admit an indefinite and unspecified spiritual form of life after death ${ }^{39}$.

Figure 3. Opinion on life after death

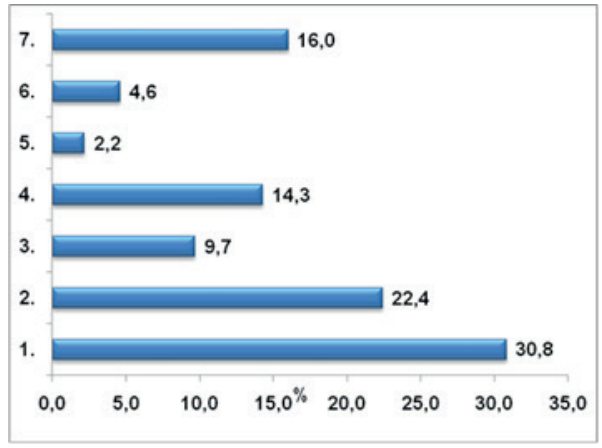

Source: Sak P., in Proměny české mládeže: 1993/1, 1997/1, 2002/2.

\section{Conclusion}

On the basis of different sociological studies conducted after the fall of communism in the Czech Republic and reflecting today's religious situation in Czech society, it

39 See P. Sak, Proměny české mládeže, p. 107. 
is possible to grasp the complexity of various processes significantly influencing family life. Secularization, globalization, religious pluralism, the large number of nonbelievers, values, lack of authority of traditional institutions and churches, relatively extensive belief in supernatural appearances and occultism - all have a significant influence on transmitting the faith in the family. They complicate the natural spiritual formation of young generations.

The influence of family on a value preference of religion is relatively strong; therefore, family continues to be an important element in religious formation of children. The studies show that if religion is important for parents, this attitude is inherited by $40 \%$ of children. On the contrary, if parents do not consider religion important, the attitude is inherited by almost $100 \%$ of children ${ }^{40}$. In the Czech Republic, the younger generation (at age 30 ) has no sense of duty to transmit the faith to their children, in contrast to the case of older generations.

In the case of traditional religiosity, it is possible to speak of an inherited religious identity. Only one fifth of traditional believers have obtained their faith outside the family. In the case of non-traditional religious forms, the belief has not been inherited within the family, mainly because it is a relatively recent, post-communist affair ${ }^{41}$.

It is possible to assume that Christianity will not be a mass movement, but a religion of mature people and of Christians who are aware of the value of the faith they confess. We can hope that these people will have a great sense of responsibility to transmit their faith to younger generations.

40 See R. Tichý, M. Vávra, Náboženství z jiného úhlu, Brno 2012, CDK, p. 29-33.

41 See R. Tichý, M. Vávra, Náboženství z jiného úhlu, p. 41-42; Rodzina. Bezcenny dar izadanie, J. Stala, E. Osewska (eds.), Radom 2006, Polwen; J. Stala, Familienkatechese in Polen um die Jahrhundertwende. Probleme und Herausforderungen, Tarnów 2008, Biblos; J. Stala, E. Osewska, Anders erziehen in Polen. Der Erziehungs- und Bildungsbegriff im Kontext eines sich ständig verändernden Europas des XXI. Jahrhunderts, Tarnów 2009, Polihymnia; J. Stala, W kierunku integralnej edukacji religijnej w rodzinie, Tarnów 2010, Polihymnia; Religious Education / Catechesis in the Family. A European Perspective, E. Osewska, J. Stala (eds.), Warszawa 2010, UKSW; Nauki o rodzinie w stużbie rodziny, J. Stala (ed.), Kraków 2014, UPJPII. 


\section{Bibliography}

Czech Statistical Office, Statistical Yearbook of the Czech Republic 2012, Praha 2012, Available online. http://www.czso.cz/csu/2012edicniplan.nsf/t/A6004C2345/\$File/000112.pdf.

Hamplová D., Náboženství a nadpřirozeno ve společnosti, Praha 2000, Sociologický ústav AV ČR. Hamplová D., Náboženství a pohlaví: Proč jsou ženy zbožnější než muži?, Sociologický časopis, Sociologický ústav AV ČR, Praha (2011), 47, 2, p. 297-323.

Laudátová M., Vido R., Současná česká religiozita v generační perspektivě in České hodnotové proměny 1991-2008. (European Values Study), “Sociální Studia” 4 (2010) (vol. 7), p. 37-61.

Lužný D., Navrátilová J., Náboženství a sekularizace v České republice, in: L. Rabušic (ed.), České hodnoty 1991-1999, Brno 2001, Masarykova universita, p. 111-125.

Ministry of Culture. 2013 (28.11.2013). Available on WWW: http://www.mkcr.cz/cz/cirkvea-nabozenske-spolecnosti/registrace-a-evidence/data-registrace-cirkvi-a-nabozenskychspolecnosti-a-svazu-cirkvi-a-nabozenskych-spolecnosti-11263/

Nauki o rodzinie w służbie rodziny, J. Stala (ed.), Kraków 2014, UPJPII.

Pištora L., Občan a jeho vztah k náboženství či víře v údajích sčítánílidu, “Teologie \& Společnost” I. (IX.) 2003, 6, p. 33-36.

Rabušic L., České hodnoty 1991-1999, Brno 2001, Masarykova universita.

Rabušic L., Hamanová J., Hodnoty a postoje v ČR 1991-2008 (Pramenná publikace European Value Study), Brno 2009, Munipress; České hodnotové proměny 1991-2008 (European Values Study), "Sociální Studia" 4 (2010) vol. 7.

Rabušic L., Petrová Kafková M., České hodnotové proměny 1991-2008 (Euroepan Values Study), Brno 2010, Fakulta sociálních studií Masarykovy univerzity.

Religious Education / Catechesis in the Family. A European Perspective, E. Osewska, J. Stala (eds.), Warszawa 2010, UKSW.

Rodzina. Bezcenny dar i zadanie, J. Stala, E. Osewska (eds.), Radom 2006, Polwen.

Sak P., Proměny české mládeže, Praha 2000, Nakladatelství Petrklíč.

Sak P., Saková K., Mládež na křižovatce, Praha 2004, Svoboda Servis.

Spousta J., Changes in Religious Values in the Czech Republic, "Sociologický časopis / Czech Sociological Review" 38 (2002), p. 345-364.

Spousta J., České církve očima sociologických výzkumů, in: J. Hanuš (ed.), Náboženství v době společenských změn, Masarykova universita, Brno 1999, p. 73-90.

Stala J., Familienkatechese in Polen um die Jahrhundertwende. Probleme und Herausforderungen, Tarnów 2008, Biblos.

Stala J., Osewska E., Anders erziehen in Polen. Der Erziehungs- und Bildungsbegriff im Kontext eines sich ständig verändernden Europas des XXI. Jahrhunderts, Tarnów 2009, Polihymnia.

Stala J., W kierunku integralnej edukacji religijnej w rodzinie, Tarnów 2010, Polihymnia. 
Statistical Yearbook of the Czech Republic 2012, Praha 2012, Available online. (http://www.czso. cz/csu/2012edicniplan.nsf/t/A6004C2345/\$File/000112.pdf).

Tichý R., Vávra M., Náboženství z jiného úhlu, Brno 2012, CDK, p. 29-33. 